Surgeons 2021 Annual Scientific Meeting, which will be held virtually, January 29-31, 2021.

10. Full COVID-19 Registry Dashboard. Accessed November 19, 2020. Available at: https://www.elso.org/Registry/FullCOVID19RegistryDashboard.aspx.

11. World Health Organization. Clinical management of severe acute respiratory infection (SARI) when COVID-19 disease is suspected. Interim guidance. 2020. Accessed April 7, 2020. Available at: https://www.who.int/docs/defaultsource/coronaviruse/clinical-management-of-novel-cov.pdf.

12. Interim Clinical Guidance for Management of Patients with Confirmed Coronavirus Disease (COVID-19). Accessed April 7, 2020. Available at: https://www.cdc. gov/coronavirus/2019-ncov/hcp/clinical-guidance-management-patients.html.

13. Bartlett RH, Ogino MT, Brodie D, McMullan DM, Lorusso R, MacLaren G, et al. Initial ELSO guidance document: ECMO for COVID-19 patients with severe cardiopulmonary failure. ASAIO J. 2020;66:472-4.
14. Rajagopal K, Keller S, Akhanti B, Bime C, Loyalka P, Cheema FH, et al Advanced pulmonary and cardiac support of COVID-19 patients: emerging recommendations from ASAIO_a "Living Working Document." ASAIO J. 2020; 66:588-98.

15. Lang C, Jaksch P, Hoda MA, Lang G, Staudinger T, Tschernko E, et al. Lung transplantation for COVID-19-associated acute respiratory distress syndrome in a PCR-positive patient. Lancet Respir. 2020;8: 1057-60.

16. Han W, Zhu M, Chen J, Zhang J, Zhu S, Li T, et al. Lung transplantation for elderly patients with end-stage COVID-19 pneumonia. Ann Surg. 2020;272: e33-4.

17. Machuca TN, Cypel M, Bharat A. Comment on let's build bridges to recovery in COVID-19 ARDS, not burn them! Ann Surg. November 17 [Epub ahead of print].
See Article page 1071.

\section{Commentary: Heroic tales from a national tragedy}

\section{Jacob A. Klapper, MD, FACS}

The manuscript by Shih and colleagues ${ }^{1}$ is an excellent description of a large institution's experience using extracorporeal membrane oxygenation (ECMO) during the first 6 months of the pandemic. In so doing, they have highlighted a number of key elements to realizing success with this resource as it is deployed in the fight against the virus.

First, multidisciplinary involvement is essential when considering patients for potential transfer from an outside institution or an affiliated hospital within the system. As the authors demonstrate, it takes an organized, multidisciplinary team to determine the appropriateness of ECMO deployment. This, of course, begins with a collegial discussion with the outside provider that includes pulmonologists, surgeons, and perfusionists. The benefits of multiple providers fielding such calls is that each practitioner's individual expertise enables the team to select appropriate patients for transfer.

From the Division of Cardiothoracic Surgery, Duke University Medical Center, Durham, NC.

Disclosures: The author reported no conflicts of interest.

The Journal policy requires editors and reviewers to disclose conflicts of interest and to decline handling or reviewing manuscripts for which they may have a conflict of interest. The editors and reviewers of this article have no conflicts of interest.

Received for publication Nov 22, 2020; revisions received Nov 22, 2020; accepted for publication Nov 23, 2020; available ahead of print Dec 3, 2020.

Address for reprints: Jacob A. Klapper, MD, FACS, Division of Cardiothoracic Surgery, DUMC 3954, Durham, NC 27710 (E-mail: Jacob.klapper@duke.edu).

J Thorac Cardiovasc Surg 2022;163:1082-3

0022-5223/\$0.00

Published by Elsevier Inc. on behalf of The American Association for Thoracic Surgery

https://doi.org/10.1016/j.jtcvs.2020.11.119
Check for updates

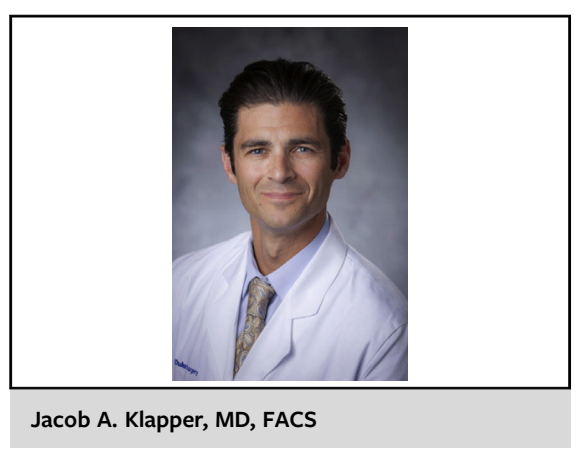

CENTRAL MESSAGE

VV ECMO continues to be an invaluable resource in the treatment of ARDS. This fact has perhaps never been more relevant than in our fight against COVID-19.

The downstream implications of deliberate patient selection are significant for multiple reasons. First, ECMO is, of course, a limited resource, as are the beds these patients occupy. ECMO use in patients for whom there is very little chance for meaningful recovery has the potential to be both dispiriting to the team and may give family members false hope. In addition, every ECMO deployment in a patient who is unlikely to survive means that one less bed, perfusionist, machine, or skilled nurse is available for the next patient who may truly benefit.

Speaking of intensive resource use, reading this comprehensive review serves as a firm reminder of how this virus impacts the system as a whole, particularly the emotional well-being of patient and care providers alike. For instance, of the 37 patients included in this analysis, $56.8 \%$ survived 
to discharge, but 12 of these patients required discharge to a long-term acute care or rehab hospital and 2 of these individuals required readmission for ventilator weaning. Although one-third of those who survived were discharged directly home, we can assume that their recuperation continued for a significant length of time. In sum, the pandemic has exacted a toll not only on its victims but also on those who survive and the nurses and doctors who make exhaustive efforts to save a life.

Postpandemic, I believe that the role of venovenous (VV) ECMO in rescuing any number of patients who are positive for coronavirus disease 2019 will be heralded as a success story. As the authors mention, they chose not to include in their analysis the 2 patients who were initiated on venoarterial (VA) ECMO. Undoubtedly, the effectiveness of VA ECMO for this disease will not mirror that of VV ECMO. While a consensus statement from the ELSO Guideline
Working Group does not specifically recommend against VA ECMO, enhanced discretion must be taken when selecting these patients, as anecdotal evidence has not been encouraging. ${ }^{2}$

The authors should be commended for their hard work in taking care of their patients and describing their experience. Unfortunately, this paper is just further evidence for what hasn't been done on a larger scale to prevent human suffering. What could have been will never be. Tragic.

\section{References}

1. Shih E, DiMaio JM, Squiers JJ, Banwait JK, Meyer DM, George TJ, et al. Venovenous extracorporeal membrane oxygenation for patients with refractory coronavirus disease 2019 (COVID-19): multicenter experience of referral hospitals in a large healthcare system. J Thorac Cardiovasc Surg. 2022;163:1071-9.e3.

2. Shekar K, Badulak J, Peek G, Boeken U, Dalton HJ, Arora L, et al. Extracorporeal life support organization coronavirus disease 2019 interim guidelines: a consensus document from an international group of interdisciplinary extracorporeal membrane oxygenation providers. ASAIO J. 2020;66:707-21.
See Article page 1071.

\section{Commentary: COVID-19 extracorporeal membrane oxygenation: A long way from home}

\author{
David A. Baran, MD, FACC, FSCAI, FHFSA, ${ }^{a}$ and \\ Hannah Copeland, $\mathrm{MD}^{\mathrm{b}}$
}

Before the current COVID-19 crisis, there was the H1N1 influenza pandemic in 2009. ${ }^{1,2}$ This pathogen was associated with a high incidence of severe respiratory failure, and in that setting, use of veno-veno extracorporeal membrane oxygenation (VV-ECMO) became much more

\footnotetext{
$\overline{\text { From }}{ }^{\text {aAdvanced }}$ Heart Failure Center, Sentara Heart Hospital, Eastern Virginia Medical School, Norfolk, Va; and ${ }^{\mathrm{b} C a r d i o v a s c u l a r}$ Surgery, Lutheran Hospital, and Surgery, Indiana University School of Medicine, Fort Wayne, Ind.

Disclosures: Dr Baran has consulted for Getinge, LivaNova, Abiomed, and Abbott; has spoken for Pfizer; and serves on steering committees for Procyrion and CareDx. Dr Copeland has served as a consultant for Bridge to Life and Paragonix.

The Journal policy requires editors and reviewers to disclose conflicts of interest and to decline handling or reviewing manuscripts for which they may have a conflict of interest. The editors and reviewers of this article have no conflicts of interest.

Received for publication Dec 1, 2020; revisions received Dec 1, 2020; accepted for publication Dec 2, 2020; available ahead of print Dec 9, 2020.

Address for reprints: Hannah Copeland, MD, Lutheran Hospital, 7910 W Jefferson Blvd, Suite 102, Fort Wayne, IN 46804 (E-mail: hannahcopeland411@gmail.com). J Thorac Cardiovasc Surg 2022;163:1083-4 $0022-5223 / \$ 36.00$

Copyright (c) 2021 by The American Association for Thoracic Surgery https://doi.org/10.1016/j.jtcvs.2020.12.011
}

\section{Check for updates}

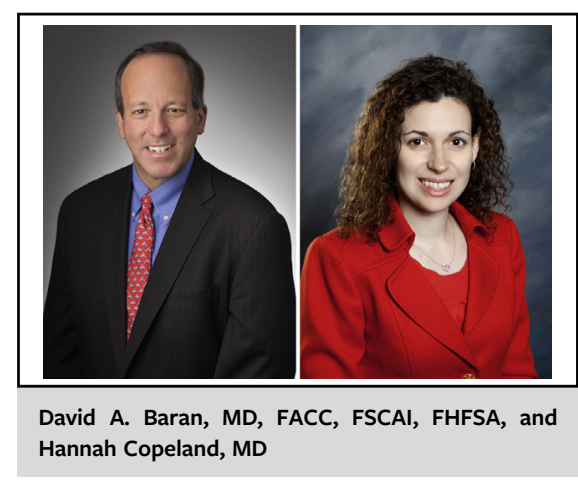

CENTRAL MESSAGE

Interest is increasing in the use of rescue venovenous extracorporeal membrane oxygenation to treat patients with COVID-19 infection. Careful patient selection and preparation for lengthy

common in support times are imperative. expert centers. $^{3-5}$ The

majority of injuries from H1N1 were respiratory, although other effects were noted. Now, 11 years later, the world is battling the SARS-CoV2 virus and COVID-19. Naturally, the inclination is to examine previous strategies, in particular VV-ECMO. 